\title{
RESEARCH ON THE EVALUATION OF SYNERGY EFFECT OF GREEN SUPPLY CHAIN MANAGEMENT IN IRON AND STEEL ENTERPRISES: BAOSTEEL CASE STUDY
}

\author{
${ }^{1}$ Wenlong YAO, ${ }^{1}$ Radim LENORT, ${ }^{1}$ Martin ČECH \\ ${ }^{1}$ Faculty of Materials Science and Technology, VŠB - Technical University of Ostrava, Ostrava, \\ Czech Republic,EU, marcoe@163.com
}

https://doi.org/10.37904/metal.2020.3650

\begin{abstract}
Based on the collaborative management theory of green supply chain, the aim of this paper is to establish the evaluation index system of coordination effect of steel enterprise green supply chain management from two aspects of economic performance and green performance. It selects Baosteel as the research object, evaluates the collaborative management of green supply chain by means of catastrophe progression method and coupling coordination degree model, and analyses the relevant data of enterprises from 2010 to 2019 Management level and the synergistic effect of green performance development. The results show that although the overall performance is fluctuating in the past 10 years, its green performance and economic performance generally maintain a good level, and there is a certain space for improvement.
\end{abstract}

Keywords: Green supply chain, iron and steel industry, synergy effect, catastrophe progression method, coupling and co scheduling

\section{INTRODUCTION}

Green supply chain is based on green manufacturing and supply chain management technology. The supply chain includes four groups including suppliers, manufacturers, distributors, and users. It aims to maximize the use of resources and minimize the impact on the environment in the process of material acquisition, processing, packaging, storage, transportation, use and disposal the damage. According to the data of China Iron and steel industry yearbook, China's iron and steel production accounts for about $50 \%$ of the global production. Due to the high iron and steel production, the energy consumption is large, and there are many industrial wastes. Among them, the total emission of wastes accounts for $16 \%$ of the national industrial waste emissions. According to relevant data, the comprehensive recovery and utilization rate of steel waste in China is about $58 \%$, far below the world advanced level of $98 \%$.

Research on green supply chain of iron and steel includes types of iron and steel wastes [1], output, potential, value [2], transportation model [3], concept of Green Reverse Logistics in iron and steel industry [4], cost of collection and transportation [5], operation mode [6], performance evaluation of green supply chain management in iron and steel enterprises [7], supply chain planning [8], strategy and countermeasure [9], reverse logistics among high energy consuming industrial clusters [10], the evaluation and selection of the recovery mode of scrap iron and steel [11] and the efficiency of supply chain [12]. However, the research on the synergy of green supply chain collaborative management in iron and steel enterprises is still relatively weak.

In the process of promoting circular economy, the green supply chain management of iron and steel enterprises should take themselves as the core, and study the synergistic effect of green supply chain management from two angles of internal green manufacturing and external industrial environment governance, so as to maximize the comprehensive benefits of circular economy. Therefore, on the basis of the existing research results, this paper attempts to build a green supply chain synergy evaluation model for empirical research. 


\section{EVALUATION MODEL OF SYNERGY EFFECT OF GREEN SUPPLY CHAIN IN IRON AND STEEL ENTERPRISES}

\subsection{Concept of synergy evaluation of green supply chain in iron and steel enterprises}

Green supply chain management performance evaluation refers to the evaluation of the actual operation of the supply chain. According to the evaluation results, the advantages and disadvantages of the supply chain in the operation are found, and the existing problems in the supply chain are studied and improved plans and measures are put forward. The green performance of an iron and steel enterprise is the centralized embodiment of the collaborative operation results of each node enterprise in the implementation of green supply chain management. Taking Baosteel as an example, this paper evaluates its economic performance and green performance, and evaluates the synergy effect of economic performance and green performance of iron and steel enterprises with the question of whether Chinese iron and steel enterprises should sacrifice environment and waste resources while pursuing economic efficiency.

\subsection{Module analysis of internal and external green performance of iron and steel enterprises}

Under the theoretical background of circular economy, according to the classification of steel waste and nonsteel waste, this paper divides the green performance evaluation of steel enterprises after implementing green supply chain management into two evaluation modules: internal green performance and external green performance. Among them, the evaluation of internal green performance reflects the results of all kinds of iron and steel wastes returned from the downstream process to the upstream process for reprocessing and reuse in the production process of iron and steel enterprises [5]. The external green performance is the result evaluation of industrial environmental governance of iron and steel enterprises through various projects, technical improvement or introduction of energy-saving equipment [13]. The internal and external green performance evaluations of iron and steel enterprises reflect the achievements of green supply chain management.

\section{EVALUATION MODEL CONSTRUCTION OF COLLABORATIVE EFFECT OF GREEN SUPPLY CHAIN MANAGEMENT IN IRON AND STEEL ENTERPRISES}

\subsection{Establishment of evaluation index system for synergy effect of green supply chain management in iron and steel enterprises}

There are two aspects in the synergy effect of green supply chain collaborative management in iron and steel enterprises, one is the synergy between economic performance and green performance, the other is the synergy between internal green performance and external green performance. Among them, the economic performance subsystem is composed of two parts: financial value index and output index; the green performance subsystem is composed of two parts: the internal green performance reflecting the recycling of iron and steel waste and the external green performance reflecting the degree of external environmental pollution of iron and steel enterprises. The specific evaluation index system of synergy is shown in Table 1:

Table 1 Evaluation index system of synergy effect of sustainable supply chain management in iron and steel enterprises

\begin{tabular}{|l|l|l|}
\hline First-level index & Second-level index & \multicolumn{1}{|c|}{ Third-level index } \\
\hline \multirow{4}{*}{$\begin{array}{l}A_{1} \text {-Economic } \\
\text { performance }\end{array}$} & \multirow{3}{*}{$B_{1}$-Financial value } & $C_{1}$ - Net profits \\
\cline { 3 - 3 } & & $C_{2}$ - Gross revenues \\
\cline { 3 - 3 } & & $C_{3}$ - Total assets \\
\cline { 3 - 3 } & & $C_{4}$ - Return on equity \\
\cline { 3 - 3 } & $B_{2}$-Operation value & $C_{5}$ - Crude steel output \\
\hline
\end{tabular}




\begin{tabular}{|c|c|c|}
\hline & & $C_{6}$ - Sales for commodity blank \\
\hline & & $C_{7}-$ Number of suppliers with environmental management certification \\
\hline \multirow{6}{*}{$\begin{array}{c}A_{2} \text {-Green } \\
\text { performance }\end{array}$} & \multirow{3}{*}{$\begin{array}{l}B_{3} \text {-Internal green } \\
\text { performance }\end{array}$} & $C_{8}$ - Comprehensive energy consumption per ton of steel \\
\hline & & $C_{9}-$ New water consumption per ton of steel \\
\hline & & $C_{10}$ - Total amount of residual energy recovery \\
\hline & \multirow{3}{*}{$\begin{array}{c}B_{4} \text {-External green } \\
\text { performance }\end{array}$} & $C_{11}$ - The emission of $\mathrm{SO}_{2}$ per ton of steel \\
\hline & & $C_{12}$ - The emission of smoke and dust per ton of steel \\
\hline & & $C_{13}$ - The emission of NOx per ton of steel \\
\hline
\end{tabular}

\subsection{Evaluation model construction of synergy effect of steel green supply chain management}

First, the data is standardized, and then the catastrophe progression method is used to evaluate each index layer, because this method does not need to calculate the weight of the index, but only considers the relative importance of each evaluation index to rank the indexes hierarchically, so as to reduce the subjectivity of the evaluation [14]. Finally, the coupling coordination model is used to evaluate the synergy among the systems.

\subsubsection{Index data processing}

In the above index system, there are both positive and negative indexes. In this paper, range transformation method is used to deal with the index dimensionless, and the value of the original data is converted between $[0,1]$. For positive indicators, set $y_{i j}=\frac{x_{i j}-x_{\min (i)}}{x_{\max (i)}-x_{\min (i)}}$ to transform; for negative indicators, set $y_{i j}=\frac{x_{\max (i)}-x_{i j}}{x_{\max (i)}-x_{\min (i)}}$ to transform.

\subsubsection{Evaluation using catastrophe progression method}

In this paper, catastrophe progression evaluation method is used to calculate the evaluation value of each index layer, that is, the normalization formula of catastrophe system is derived from the bifurcation point set equation of catastrophe system. When each control variable satisfies the bifurcation point set equation, the system will have a sudden change, which can be transformed into a catastrophe fuzzy membership function to obtain a normalization formula.

- $\quad$ The normalization formula of cusp mutation is as follows : $x_{a}=a^{1 / 2}, x_{b}=b^{1 / 3}$

- The normalization formula of swallowtail mutation is as follows: $x_{a}=a^{1 / 2}, x_{b}=b^{1 / 3}, x_{c}=c^{1 / 4}$

- The normalization formula of butterfly mutation is as follows : $x_{a}=a^{1 / 2}, x_{b}=b^{1 / 3}, x_{c}=c^{1 / 4}, x_{d}=d^{1 / 5}$

When using the normalization formula for evaluation, the indicators representing each level should consider the principle of complementarity and non-complementarity. If there is no obvious interaction among the control variables in the same indicator layer, the control variables in the same indicator layer are non-complementary; if there is obvious interaction among the control variables in the same indicator layer, the control variables in the same indicator layer are complementary. Then, according to the complementarity between the indicators, the principle of average value is adopted for the indicators of the complementary relationship, and the principle of "Minimax criterion" is adopted for the indicators of the non-complementary relationship, so as to get the comprehensive evaluation value of the previous level of indicators.

\subsubsection{Synergy evaluation}

Coupling coordination is a proper term in physics to describe the phenomenon that two or more subsystems of different properties in a system interact, influence, promote each other and even co evolve based on the 
connection of certain properties [15]. Evaluating based on the catastrophe progression method, the values of internal green performance and external green performance, as well as economic performance and green performance can be obtained. In order to evaluate the synergistic effect between the subsystems, the coordination degree (coefficient) model of the two systems is applied as in equations (1) and (2):

$C_{i}=\left[\frac{F\left(x_{i}\right) \times G\left(y_{i}\right)}{\left(\frac{F\left(x_{i}\right)+G\left(y_{i}\right)}{2}\right)^{2}}\right]^{2}$

$D_{i}=\sqrt{C_{i} \times Q_{i}}, Q_{i}=\alpha F\left(x_{i}\right)+\beta G\left(y_{i}\right)$

where:

$D_{i}$ - the coordinated development degree of the system in the $i$ year

$C_{i}$ - the coordination coefficient of the two systems in the $i$ year

$Q_{i}$ - the comprehensive evaluation value of the subsystem in the $i$ year

$C_{i}$ only represents the levels of the interaction between systems, and then introduces the coupling coordination model to reflect the coordination degree of the interaction between systems.

$\alpha, \beta$ of the $i$ year are the weight coefficients of the two subsystems (economic performance and green performance). Considering that the two subsystems play an important role in the sustainable development of the green supply chain of iron and steel enterprises, the weight coefficient of $\alpha, \beta$ is 0.5 each.

\section{EMPIRICAL RESEARCH}

\subsection{Data sources}

In this paper, Baosteel Co., Ltd. is taken as the research object to evaluate the synergy effect of its green supply chain management from 2010 to 2019. The index data in this paper are from The sustainable development report of Baoshan Iron and Steel Co., Ltd in 2010-2019., The social responsibility report of Baosteel Group Co., Ltd. in 2010-2015., The social responsibility report of Baosteel Group Co., Ltd. in 20162018. and The annual report of Baoshan Iron and Steel Co., Ltd. in 2010-2019.

\subsection{Evaluation of synergy effect of Baosteel's green supply chain management}

First, the original data is processed dimensionless to get the evaluation value. Before evaluating the performance of green supply chain in iron and steel enterprises, the catastrophe progression corresponding to each level of index lock should be determined first, and the corresponding normalization formula should be selected. Because the index data of green supply chain performance evaluation in the selected case is mostly about the data in ten years, the data in 2010 is taken as an example to demonstrate the evaluation process here.

The financial value $B_{1}$ consists of profit $C_{1}$, total operating revenue $C_{2}$, total assets $C_{3}$ and return on net assets $C_{4}$. According to the principle of complementarity, the financial value indexes $B_{1}$ are as follows:

But a non-complementary cusp catastrophe model is composed of financial value and operational performance. According to the principle of non-complementarity, the economic performance is as follows: $x_{B_{1}}=\frac{x_{c_{1}}^{1 / 2}+x_{c_{2}}^{1 / 3}+x_{c_{3}}^{1 / 4}+x_{c_{4}}^{1 / 5}}{4}=\frac{0.5668^{1 / 2}+0.2709^{1 / 3}+0.0000^{1 / 4}+0.9390^{1 / 5}}{4}=0.5968$. But a non-complementary cusp catastrophe model is composed of financial value $B_{1}$ and operational performance $B_{2}$. According to the principle of non complementarity, the economic performance $A_{1}$ is as follows: $x_{A_{1}}=\min \left\{x_{B_{1}}^{1 / 2}, x_{B_{2}}^{1 / 3}\right\}=$ $\min \left\{0.5968^{1 / 2}, 0.2961^{1 / 3}\right\}=0.6665$. By analogy, the performance evaluation and coordinated development of 
Baosteel's green supply chain management in 2010-2019 are shown in Table 2, and the performance evaluation results and coordinated development of internal and external green supply chain in 2010-2019 are shown in Table 3.

Table 2 Performance evaluation results and coordinated development degree of internal and external green supply chain of Baosteel in 2010-2019

\begin{tabular}{|c|c|c|c|c|c|c|c|c|c|c|}
\hline Performance & $\mathbf{2 0 1 0}$ & $\mathbf{2 0 1 1}$ & $\mathbf{2 0 1 2}$ & $\mathbf{2 0 1 3}$ & $\mathbf{2 0 1 4}$ & $\mathbf{2 0 1 5}$ & $\mathbf{2 0 1 6}$ & $\mathbf{2 0 1 7}$ & $\mathbf{2 0 1 8}$ & $\mathbf{2 0 1 9}$ \\
\hline $\begin{array}{c}\text { Internal } \\
\text { performance }\end{array}$ & 0.6319 & 0.5747 & 0.2917 & 0.3102 & 0.2081 & 0.6118 & 0.6509 & 0.8701 & 0.9867 & 1.0000 \\
\hline $\begin{array}{c}\text { External } \\
\text { performance }\end{array}$ & 0.1361 & 0.4104 & 0.6464 & 0.7145 & 0.7998 & 0.8980 & 0.9264 & 0.9522 & 0.9577 & 1.0000 \\
\hline $\begin{array}{c}\text { The } \\
\text { development of } \\
\text { internal and } \\
\text { external } \\
\text { coordinated } \\
\text { performance }\end{array}$ & 0.3614 & 0.6823 & 0.5870 & 0.6044 & 0.4653 & 0.8376 & 0.8610 & 0.9526 & 0.9858 & 1.0000 \\
\hline
\end{tabular}

Table 3 Performance evaluation and coordinated development of Baosteel's green supply chain in 20102019

\begin{tabular}{|c|c|c|c|c|c|c|c|c|c|c|}
\hline Performance & 2010 & 2011 & 2012 & 2013 & 2014 & 2015 & 2016 & 2017 & 2018 & 2019 \\
\hline $\begin{array}{c}\text { Economic } \\
\text { performance }\end{array}$ & 0.6665 & 0.7962 & 0.7738 & 0.7560 & 0.7183 & 0.3860 & 0.9124 & 0.9336 & 0.9528 & 0.9442 \\
\hline $\begin{array}{c}\text { Green } \\
\text { performance }\end{array}$ & 0.5144 & 0.7431 & 0.5401 & 0.5570 & 0.4562 & 0.7822 & 0.8068 & 0.9328 & 0.9857 & 1.0000 \\
\hline $\begin{array}{c}\text { Overall } \\
\text { performance }\end{array}$ & 0.8012 & 0.8923 & 0.8144 & 0.8228 & 0.7698 & 0.6213 & 0.9309 & 0.9662 & 0.9761 & 0.9717 \\
\hline $\begin{array}{c}\text { The } \\
\text { development of } \\
\text { economic and } \\
\text { green } \\
\text { coordinated } \\
\text { performance }\end{array}$ & 0.7557 & 0.8763 & 0.7849 & 0.7916 & 0.7282 & 0.6764 & 0.9236 & 0.9660 & 0.9842 & 0.9851 \\
\hline
\end{tabular}

\subsection{Analysis on the evaluation results of synergy effect of Baosteel's green supply chain management}

\subsubsection{Analysis of internal and external green performance and synergy}

Combined with Figure 1 and Table 3, it can be seen that the fluctuation of Baosteel's internal green performance and the fluctuation of its economic performance converged during 2010-2019. The difference is that in 2014, Baosteel's economic performance was at a high inflection point, crude steel output was 44.5 million tons, internal green performance was at the lowest level in ten years, and in 2015, it was also at a low inflection point of economic performance, with a crude steel output of only 36.11 million tons. The reduction of output and the firm's green supply chain management led to a significant improvement in its internal performance. It shows that the change of green supply chain management level and steel production affects the change of green performance. In the past decade, Baosteel's external green performance has been continuously improved. Since 2017, Baosteel's coordinated development of internal and external green performance has been in a high-quality coordinated state. 


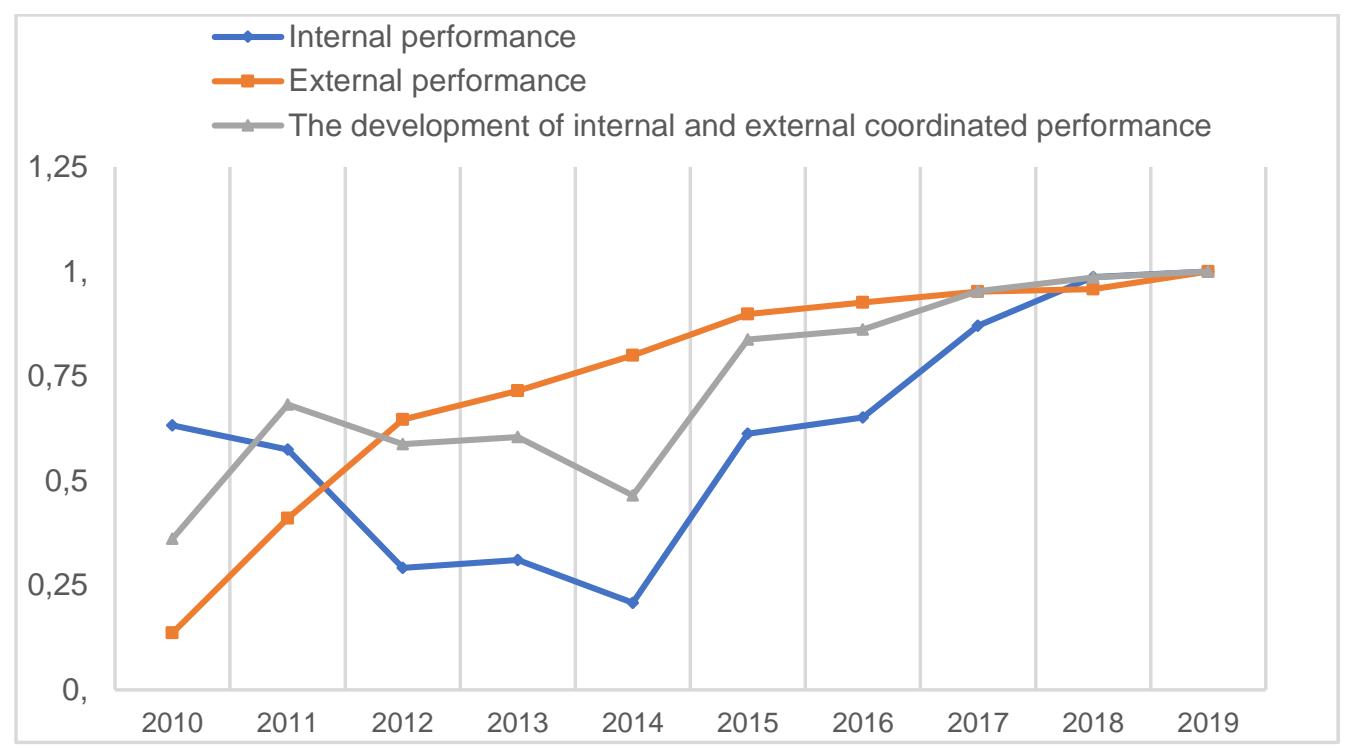

Figure 1 Analysis of Baosteel's internal and external green performance and synergies in 2010-2019

\subsubsection{Baosteel performance system and synergy analysis}

From Figure 2, it can be seen that the economic performance of Baosteel from 2010 to 2011 was rising. However, combined with the original data, it can be found that behind the rise, there was a decrease in profits. It was because the total supply of steel in China increased by $9.9 \%$ in 2011 compared with that in 2010 , and the increase in supply led to a double drop in steel prices and corporate profits. The trend of profit decline continued to 2015. During this period, structural overcapacity of China's iron and steel industry, and in 2015, the overall economic development of China slowed down, the demand for iron and steel products declined, and the return on net assets of Baosteel in 2015 was only $0.9 \%$. Since 2016, China's domestic economy has gradually recovered. The steel market has benefited from the growth of domestic infrastructure, real estate and other industries, and the demand for steel products has increased. In 2017, Baosteel and Wuhan Iron and Steel Group Co., Ltd. merged to establish Baowu. Wuhan Iron and Steel became a wholly owned subsidiary of Baosteel. After the merger, Baosteel's return on net assets reached the highest $12.7 \%$ in 10 years.

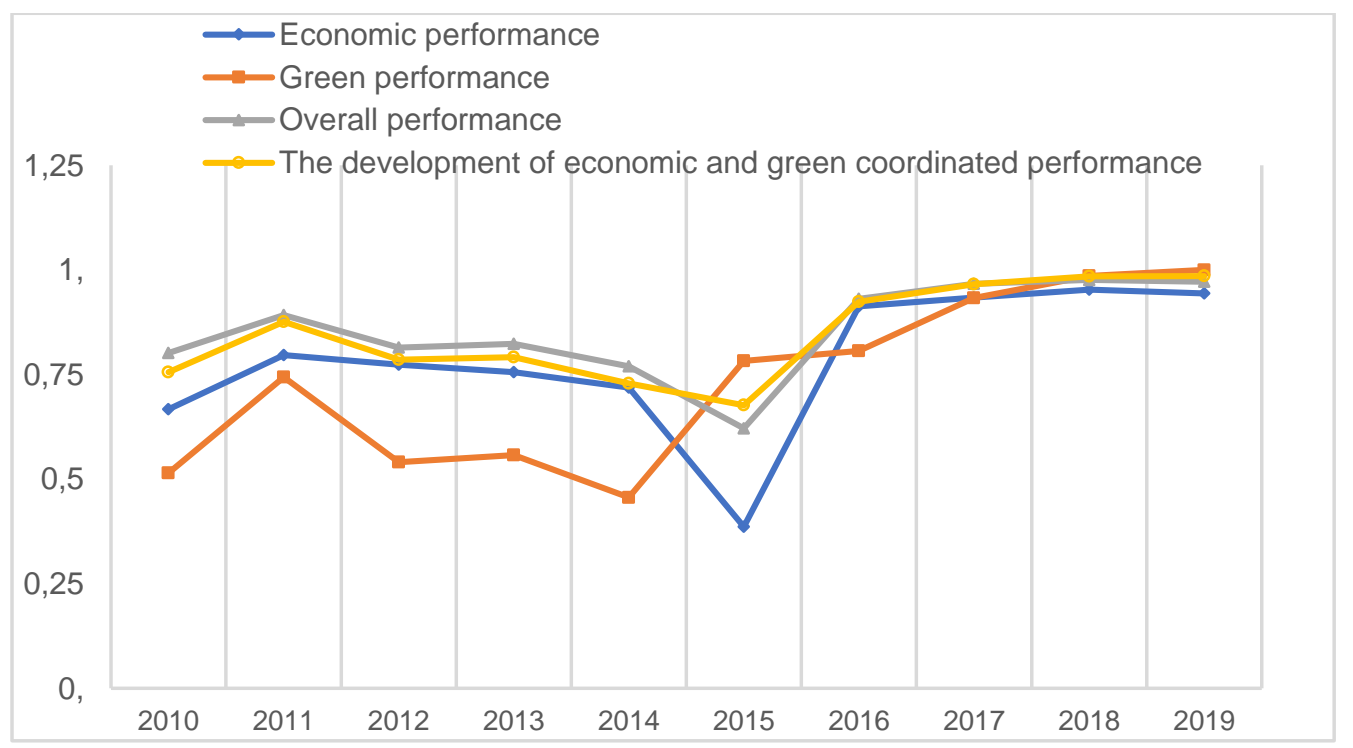

Figure 2 comprehensive performance and synergy evaluation of Baosteel's green supply chain in 2010-2019 
In the past ten years, the fluctuation of the total performance was similar to the economic performance of the enterprise with a smaller amplitude. Combined with the previous analysis of the internal and external green performance and coordination degree of the enterprise, before 2014, the green performance of the enterprise was affected by certain economic performance, and the level of green supply chain management was lower than now, and the overall green performance showed a fluctuating trend. However, even in the context of increased production capacity and decreased profits in 2010-2015, the green performance of enterprises has not decreased much. With the improvement of economic performance, enterprises have more resources to invest in the construction of green supply chain and environmental governance, and the speed of green performance improvement is obvious. As can be seen from Figure 2, Baosteel's coordinated development of economic performance and green performance fluctuates most steadily, which shows that Baosteel has not slowed down the construction of green supply chain and relaxed the requirements for green performance due to the reduction of economic performance. In 2016-2019, the synergy value of enterprises has been above 0.9 , which is in a high-quality coordination state.

\section{MAIN RESEARCH CONCLUSIONS}

The circular economy management of high energy consuming enterprises generally goes beyond its own scope, and the synergy evaluation of green supply chain management of iron and steel enterprises should be carried out from the two aspects of economic performance and green performance, internal green performance and external green performance. The establishment of synergy evaluation index is conducive to improve the enthusiasm of enterprises to strengthen the collaborative management of green supply chain, analyse the collaborative level of internal and external green development of iron and steel enterprises, and promoting the process of green collaborative development of iron and steel enterprises; from a macro point of view, it is an objective need to evaluate the implementation of circular economy strategy and innovation driven strategy in China's iron and steel industry, and to promote the construction of green supply chain collaborative management system in the whole iron and steel industry. The application of the collaborative effect evaluation model of green supply chain management in Baosteel case shows that the model can better analyse and reflect the situation and level change of green supply chain management based on an enterprise.

\section{ACKNOWLEDGEMENTS}

The work was supported by the specific university research of Ministry of Education, Youth and Sports of the Czech Republic at VSB - Technical University of Ostrava, projects no. SP2020/61 and SP2020/61.

\section{REFERENCES}

[1] MICHLOWICZ, E., ZWOLISKA, B. Reverse logistics systems in a steel mill a full production cycle. In METAL 2011: 20th International Conference on Metallurgy and Materials. Ostrava: TANGER, 2011, pp. 1163-1168.

[2] DAVIS, J., GEYER, R., LEY, J., et al. Time - dependent material flow analysis of iron and steel in the UK: Part 2. Scrap generation and recycling. Resources, Conservation and Recycling. 2007, vol. 51, no. 1, pp. 118-140.

[3] SPENGLER, T., PUECHERT, H., PENKUHN, T. et al. Environmental integrated production and recycling management. European Journal of Operational Research. 1997, no. 2, pp. 308-326.

[4] CHEN, T. Discussion on the development of scrap reverse logistics under circular economy. Logistics Technology (Equipment). 2012, no. 22, pp. 55-57.

[5] CHEN, J., WANG, L., XIA, X.H., WANG, Y. Study on the optimization of the logistics network in the reverse supply chain of scrap iron and steel. Co-Operative Economy \& Science. 2018, no. 16, pp. 106-107.

[6] BIAN, X.Q., HAO, S.Y. Cross case study on new operation mode of iron and steel logistics enterprises. Logistics Technology. 2007, no. 04, pp. 16-21. 
[7] JI, J.H., LIU, Q.L., GUO, Z.X. Performance Appraisal of Green Supply Chain Management of Steel Enterprises. Science and Technology Management Research. 2013, vol. 33, no. 16, pp. 53-57.

[8] ZHANG, J., LIU, X., TU, Y.L. A capacitated production planning problem for closed-loop supply chain with remanufacturing. The International Journal of Advanced Manufacturing Technology. 2011, vol. 54, no. 5-8, pp. 757-766.

[9] PINTO, T.M., DIEMER, A. Supply chain integration strategies and circularity in the European steel industry. Resources, Conservation \& Recycling. 2020, vol. 153.

[10] ZHENG, J.L., ZENG, R. Research on reverse logistics system of energy - intensive industry based on circular economy. Advanced Materials Research. 2013, vol. 734-737, pp. 2012-2015.

[11] ZHENG, J.L., ZHOU, X., ZHOU, P. Evaluation and Choice of a firm's waste steel recover mode from perspective of supply side. Journal of Kunming University of Science \& Technology (social science edition). 2016, vol. 16, no. 5, pp. 59-65.

[12] ZHANG, F., REN, S.J., YIN, X.Q. Industrial Agglomeration, Technological Innovation and Green Supply Chain Efficiency: PVAR Analysis Based on Panel Data of 28 Large and Medium - sized Steel Enterprises. Forum on Science and Technology in China. 2020, no. 4, pp. 51-64.

[13] ZHANG, R.L., LU, S.C. Study on Influencing Factors Measurement of Green Supply Chain Management in Iron and Steel Enterprises. Environmental Science \& Technology. 2015, vol. 38, no. 1, pp. 188-194+204.

[14] ZHOU, Q., ZHANG, Y. Performance Evaluation of GSC Based on Catastrophe Progression Method. China Population Resources and Environment. 2008, no. 05, pp. 108-111.

[15] YUAN, K.F., ZHANG, X.X. Study on the coupling coordination degree of the strategic alliance system of the cluster supply chain. Journal of Mudanjiang Normal University (Philosophy Social Sciences Edition). 2015, no.2, pp. 20-22. 